\title{
Dormancy break in seeds of "quina" (Strychnos pseudoquina A. St.-Hil.)
}

\author{
VASCONCELOS, J.M. ${ }^{1}$; RODRIGUES, M.A. ${ }^{1}$; VASCONCELOS FILHO, S.C. ${ }^{2}$; SALES, J.F. ${ }^{2 *}$; SILVA, F.G. ${ }^{2}$; \\ SANTANA, J.G. ${ }^{2}$ \\ ${ }^{1}$ Universidade Federal de Viçosa, Departamento de Biologia Vegetal - DBV, Edifício Chitaro Shymoya/Campus \\ UFV, CEP: 36570-000 Viçosa-Brasil ' Instituto Federal de Educação, Ciência e Tecnologia Goiano/Campus de Rio \\ Verde, Caixa Postal66, CEP: 75.901-970,Rio Verde-GO *julianacefetrv@yahoo.com.br
}

\begin{abstract}
Quina" (Strychnos pseudoquina A. St. Hil) is a medicinal plant species from the Brazilian Cerrado. As its seeds show dormancy, they were subjected to the treatments precooling at $5^{\circ} \mathrm{C}$ during 7 days, pre-heating at $40^{\circ} \mathrm{C}$ during 7 days, pre-soaking in sulfuric acid PA during 5 and $15 \mathrm{~min}$, pre-soaking in boiling water during 5 and $15 \mathrm{~min}$, pre-soaking in 100 and 200 ppm gibberellic acid during $48 \mathrm{~h}$, pre-soaking in distilled water during 24 and $48 \mathrm{~h}$, and mechanical scarification to break dormancy. Counts were daily conducted from the $2^{\text {nd }}$ day after the experiment implementation until the germination stabilization at the $65^{\text {th }}$ day. The germination speed index (GSI) and the germination percentage were evaluated. Germination rates above $96 \%$ were reached in seeds pre-soaked in water during $48 \mathrm{~h}$ and substrate moistened with water or $\mathrm{KNO}_{3}$.
\end{abstract}

Key words: "quina”, medicinal plant, germination, Loganiaceae, seed dormancy

RESUMO: Superação da dormência de sementes de quina (Strychnos pseudoquina A. St.-Hil.). A quina (Strychnos pseudoquina A. St.-Hil) é espécie medicinal do Cerrado Brasileiro. As sementes apresentam dormência e, por isso, foram submetidas aos tratamentos préresfriamento a $5^{\circ} \mathrm{C}$ durante 7 dias, pré-aquecimento a $40^{\circ} \mathrm{C}$ durante 7 dias, pré-embebição em ácido sulfúrico P.A. durante 5 e 15 minutos, pré-embebição em água fervente durante 5 e 15 minutos, pré-embebição em ácido giberélico a 100 e 200 ppm, durante 48 horas, pré-embebição em água destilada durante 24 e 48 horas e escarificação mecânica, visando à superação da dormência. Foram realizadas contagens diárias entre 0 2o dia após a implantação do experimento até a estabilização da germinação, que ocorreu no 65o dia. Foram avaliados o índice de velocidade de germinação (IVG) e a porcentagem de germinação. Taxas de germinação acima de $96 \%$ foram atingidas em sementes pré-embebidas em água durante 48 horas e substrato umedecido com água ou $\mathrm{KNO}_{3}$.

Palavras-chave: quina, planta medicinal, germinação, Loganiaceae, dormência de sementes

\section{INTRODUCTION}

Cerrado is one of the regions of greatest biodiversity in the planet, with a significant degree of endemism. However, human occupation, stimulated by a series of development policies, has transformed the region into a fragmented landscape, an environment where the agro-pasture system prevails (Buschbacher, 2000). The indiscriminate use of medicinal species in popular medicine, as well as by the pharmaceutical industry, has led to a considerable reduction in the population density of some plants in areas of natural occurrence (Nadeem et al., 2000).

"Quina" (Strychnos pseudoquina)Loganiaceae - tree grows to about $4 \mathrm{~m}$ and is found mainly in Cerrado sensu stricto. This plant has been widely used in folk medicine for its aphrodisiac, tonic, and antipyretic properties and is also indicated in case of liver problems, stomach disorders and anemia (Almeida et al., 1998; Silva et al., 2005). The study of techniques to facilitate seedling production using this species is therefore of great importance, particularly because to date no such studies exist. Moreover, its leaves contain flavonoids and alkaloids, the latter also in the branches (Nicoletti et al., 1984).

Seed dormancy is a type of latency in which absence of germination is caused by obstacles in the seed itself. It is activated by a combination of specific environmental conditions such as water, temperature, photoperiod and seed position in the

Recebido para publicação em 02/12/2008

Aceito para publicação em 11/07/2009

Rev. Bras. PI. Med., Botucatu, v.13, n.4, p.507-511, 2011. 
plant. These conditions could cause the interference of one or more blocking mechanisms, preventing the transcription of the genetic message to activate the metabolic sequence that culminates in germination. Dormancy is a defense mechanism of seeds against environmental variations that hinder or prevent the normal metabolic activity during certain periods, in which there is no transcription of the genetic message. This activity is only resumed after the action of an environmental stimulation (Marcos Filho, 2005).

According to Cardoso (2007), dormancy in this species was concluded, since germination took up to three months. The aim of the present study was therefore to evaluate the most appropriate methods to break seed dormancy in Strychnos pseudoquina .

\section{MATERIAL AND METHOD}

The experiment was conducted at the Seed Laboratory of "Instituto Federal de Educação, Ciência e Tecnologia Goiano" - Rio Verde Campus. "Quina" seeds were collected from three trees at Gameleira Farm in Montes Claros de Goiás Municipality, Goiás State, Brazil (latitude S - 1606'20', longitude W 51'17'11", $466 \mathrm{~m}$ above sea level). The fruit pulp was rubbed off by hand using a steel sieve mesh under running water. Then, the seeds were allowed to dry at room temperature for several minutes until they lost all surface moisture.

The seeds were treated with fungicide Vitavax-Thiram ${ }^{\circledR}[$ Active Ingredient (carboxin + thiram): $\left.200+200 \mathrm{~g} \mathrm{~L}^{-1}\right]$, at a concentration of $300 \mathrm{~mL}$ fungicide per $100 \mathrm{~kg}$ seed.

The following treatments were applied to the seeds to break dormancy: (i) pre-cooling - on moist substrate, cooling to $5^{\circ} \mathrm{C}$ in refrigerator for 7 days; (ii) pre-heating - in an oven with free air circulation at $40^{\circ} \mathrm{C}$ during 7 days; (iii) chemical scarification - presoaking in sulfuric acid PA (98\%) during 5 and 15 min, according to each treatment. After the established period, the acid solution was removed and the seeds washed in running water to remove all acid; then, they were allowed to dry at room temperature during 60 min. (iv) immersion in boiling water - after the period of 5 and 15 min established for each treatment, the seeds were washed in tap water and allowed to dry at room temperature for $60 \mathrm{~min}$; (v) soaking in gibberellic acid - seeds were immersed in solutions of $100 \mathrm{ppm}$ and $200 \mathrm{ppm}$ gibberellic acid $\left(\mathrm{GA}_{3}\right)$ during a period of $48 \mathrm{~h}$; (vi) soaking in distilled water - seeds were immersed in distilled water during 24 and $48 \mathrm{~h}$ at room temperature; (vii) mechanical scarification - the seed tegument was abraded with sandpaper No. 80, taking care to avoid any damage to the embryo, sanding the top opposite to the embryo axis; and (viii) control intact seeds with no pretreatment.

After the treatments described above, germinated seeds were transferred to a Mangelsdorf germinator, at $25^{\circ} \mathrm{C} \pm 4^{\circ} \mathrm{C}$.

In all treatments, seeds were allowed to germinate on substrate moistened with a solution of $0.2 \% \mathrm{KNO}_{3}$ (potassium nitrate) or distilled water, using germination boxes (Gerbox) containing 2 sheets of absorbent paper moistened to 2.5 -fold the dry substrate weight.

The germination percentage and the beginning of radicle protrusion were daily counted to calculate the germination speed index (GSI), according to the formula of Maguire (1962).

The experiment had a completely randomized block, $2 \times 12$ factorial design, with 2 substrates $\times 12$ methods of breaking dormancy and 4 blocks with 15 seeds each, totaling 96 experimental units. The results were subjected to analysis of variance ( $\mathrm{F} \mathrm{0.05)}$ and the means compared by Scott-Knott test at 5\% probability, using the software SAEG (System for Genetic Analysis and Statistics).

\section{RESULT AND DISCUSSION}

"Quina" seeds began to germinate from the $13^{\text {th }}$ day onwards and this process extended to 65 days, when germination stabilized.

The highest germination speed indexes (vigour) were observed in seeds pre-soaked in water for $48 \mathrm{~h}$ on both substrates (distilled water and $\mathrm{KNO}_{3}$ ), pre-soaked in $200 \mathrm{ppm}$ gibberellic acid and pre-soaked in $\mathrm{H}_{2} \mathrm{O}$ during $24 \mathrm{~h}$ for the water-moistened substrate (Table 1). An inhibitory effect was observed for the $\mathrm{KNO}_{3}$-moistened substrate compared to water, in seeds pre-soaked in $200 \mathrm{ppm} \mathrm{GA}{ }_{3}$ and the control. Ferreira \& Gentil (2006) also found satisfactory results (70\% germination) of germination speed in tucumã (Astrocaryum aculeatum) seeds soaked in water, compared to $\mathrm{KNO}_{3}$. According to Vieira et al. (2002), soaking rice seeds in $\mathrm{GA}_{3}$ for $36 \mathrm{~h}$ is efficient to rapidly break dormancy.

The lowest vigor was observed in seeds soaked in $\mathrm{H}_{2} \mathrm{SO}_{4}$ or boiling water during 5 and $15 \mathrm{~min}$ on the substrates containing water or $\mathrm{KNO}_{3}$. The treatments of pre-heating at $40^{\circ} \mathrm{C}$, mechanical scarification and control yielded no satisfactory results for the substrate $\mathrm{KNO}_{3}$. Seed treatment with sulfuric acid resulted in a very large number of dead seeds (Table 1).

A similar result was found by Carmona et al. (1986) in a study on Stylosanthei Macrocephala seed germination. According to that author, the treatment with sulfuric acid decreased germination due to the increase in dead seeds.

An inhibitory effect of seed treatment with sulfuric acid on germination was observed at all times evaluated, regardless of the substrate (Table 2). Sulfuric acid has a corrosive effect on the seed husk, which is

Rev. Bras. PI. Med., Botucatu, v.13, n.4, p.507-511, 2011. 
TABLE 1. Germination speed index of "quina" (Strychnos pseudoquina) seeds treated with different methods to break dormancy when allowed to germinate on substrates moistened with water or soaked in $\mathrm{KNO}_{3}$ solution $(0.2 \%)$.

\begin{tabular}{|c|c|c|}
\hline \multirow[t]{2}{*}{ Treatment } & \multicolumn{2}{|c|}{ Substrate } \\
\hline & Water & $\mathrm{KNO}_{3}(0.2 \%)$ \\
\hline Pre-cooling ( $5^{\circ} \mathrm{C}$ during 07 days) & $0.22 \mathrm{Ca}^{2}$ & $0.26 \mathrm{Ba}$ \\
\hline Pre-heating ( $40^{\circ} \mathrm{C}$ during 07 days) & $0.18 \mathrm{Ca}$ & $0.04 \mathrm{Ca}$ \\
\hline Pre-soaking in $\mathrm{H}_{2} \mathrm{SO}_{4} \mathrm{PA}(98 \%)$ during $5 \mathrm{~min}$ & $0.01 \mathrm{Da}$ & $0.03 \mathrm{Ca}$ \\
\hline Pre-soaking in $\mathrm{H}_{2} \mathrm{SO}_{4} \mathrm{PA}(98 \%)$ for during $15 \mathrm{~min}$ & $0.03 \mathrm{Da}$ & $0.02 \mathrm{Ca}$ \\
\hline Pre-soaking in boiling water for during $5 \mathrm{~min}$ & $0.00 \mathrm{Da}$ & $0.00 \mathrm{Ca}$ \\
\hline Pre-soaking in boiling water for $15 \mathrm{~min}$ & $0.00 \mathrm{Da}$ & $0.00 \mathrm{Ca}$ \\
\hline Pre-soaking in 100 ppm gibberellic acid for $48 \mathrm{~h}$ & $0.40 \mathrm{Ba}$ & $0.32 \mathrm{Ba}$ \\
\hline Pre-soaking in 200 ppm gibberellic acid for $48 \mathrm{~h}$ & $0.63 \mathrm{Aa}$ & $0.34 \mathrm{Bb}$ \\
\hline Pre-soaking in $\mathrm{H}_{2} \mathrm{O}$ for $24 \mathrm{~h}$ & $0.51 \mathrm{Aa}$ & $0.47 \mathrm{Ba}$ \\
\hline Pre-soaking in $\mathrm{H}_{2} \mathrm{O}$ for $48 \mathrm{~h}$ & $0.67 \mathrm{Aa}$ & $0.77 \mathrm{Aa}$ \\
\hline Mechanical scarification & $0.31 \mathrm{Ba}$ & $0.16 \mathrm{Ca}$ \\
\hline Control & $0.30 \mathrm{Ba}$ & $0.07 \mathrm{Cb}$ \\
\hline
\end{tabular}

${ }^{z}$ Means followed by the same uppercase letter among dormancy breaking methods and lowercase letter between substrates did not differ according to Scott-Knott test at $5 \%$ probability.

TABLE 2. Germination percentage of "quina" (Strychnos pseudoquina) seeds treated with different methods to break dormancy when allowed to germinate on substrates moistened with water or soaked in $\mathrm{KNO}_{3}$ solution $(0.2 \%)$.

\begin{tabular}{|c|c|c|}
\hline \multirow[t]{2}{*}{ Treatments } & \multicolumn{2}{|c|}{ Substrate } \\
\hline & Water & $\mathrm{KNO}_{3}(0.2 \%)$ \\
\hline Pre-cooling ( $5^{\circ} \mathrm{C}$ for 07 days) & $50.00 \mathrm{Ca}^{\mathrm{Z}}$ & $55.00 \mathrm{Ba}$ \\
\hline Pre-heating ( $40^{\circ} \mathrm{C}$ for 07 days) & $36.50 \mathrm{Da}$ & $5.00 \mathrm{Db}$ \\
\hline Pre-soaking in $\mathrm{H}_{2} \mathrm{SO}_{4} \mathrm{PA}(98 \%)$ during for 5 min & $1.75 \mathrm{Ea}$ & $5.25 \mathrm{Da}$ \\
\hline Pre-soaking in $\mathrm{H}_{2} \mathrm{SO}_{4} \mathrm{PA}(98 \%)$ for $15 \mathrm{~min}$ & $6.75 \mathrm{Ea}$ & $3.50 \mathrm{Da}$ \\
\hline Pre-soaking in boiling water for $5 \mathrm{~min}$ & $0.00 \mathrm{Ea}$ & $0.00 \mathrm{Da}$ \\
\hline Pre-soaking in boiling water for $15 \mathrm{~min}$ & $0.00 \mathrm{Ea}$ & $0.00 \mathrm{Da}$ \\
\hline Pre-soaking in 100 ppm gibberellic acid for $48 \mathrm{~h}$ & $76.50 \mathrm{Ba}$ & $74.75 \mathrm{Ba}$ \\
\hline Pre-soaking in 200 ppm gibberellic acid for $48 \mathrm{~h}$ & $93.00 \mathrm{Aa}$ & $40.00 \mathrm{Cb}$ \\
\hline Pre-soaking in $\mathrm{H}_{2} \mathrm{O}$ for $24 \mathrm{~h}$ & $91.50 \mathrm{Aa}$ & $88.00 \mathrm{Aa}$ \\
\hline Pre-soaking in $\mathrm{H}_{2} \mathrm{O}$ for $48 \mathrm{~h}$ & $96.50 \mathrm{Aa}$ & $96.75 \mathrm{Aa}$ \\
\hline Mechanical scarification & $70.75 \mathrm{Ba}$ & $33.50 \mathrm{Cb}$ \\
\hline Control & $46.75 \mathrm{Ca}$ & $18.50 \mathrm{Cb}$ \\
\hline
\end{tabular}

${ }^{z}$ Means followed by the same uppercase letter among dormancy breaking methods and lowercase letter between substrates did not differ according to Scott-Knott test at $5 \%$ probability.

favorable in the case of many species, since the change in the membrane permeability allows water uptake, an essential factor that starts the germination process. The increased permeability also allows gas exchange, reduces mechanical resistance to radicle protrusion and facilitates embryo expansion (Dousseau et al., 2007). Studies with different species of other families using sulfuric acid have shown that the germination percentage effectively increased and / or the average germination time reduced, even when the time of contact with the seed was longer than that tested here. Seed germination percentage was over 
$90 \%$ for Leucaena leucocephala pre-treated for 15 or $20 \mathrm{~min}$ (Teles et al., 2000), Enterolobium contortisiliquum (Vell.) Morong for $10 \mathrm{~min}$ (Meneghello et al., 2000), and Dimorphandra mollis for 45-90 min. However, periods longer than 90 min resulted in a marked drop of viability (Hermansen et al., 2000). On the other hand, corroborating the present results, the percentage of damaged Ormosia nitida seeds, treated with sulfuric acid, strongly increased, indicating that such jeopardizing treatments should be avoided whenever possible. Despite overcoming the phenomenon of dormancy, the percentage of damaged seeds and abnormal seedlings increase significantly, leading to high incidences of bacteria and fungi (Lopes et al., 2006). For other species, even with a short exposure period (60 seconds), germination was not effectively increased by sulfuric acid, but rather harmful (Boscagli \& Sette, 2001).

Pre-heating the seeds at $40^{\circ} \mathrm{C}$ during seven days had an inhibitory effect on germination, regardless of the analyzed substrate. Different results were observed for seeds of velvet bean (Mucuna aterrima Piper et Tracy Holland) at a temperature of $55^{\circ} \mathrm{C}$ for periods between 16 and $24 \mathrm{~h}$ (Wutke et al., 1995), and exposing seeds of Brachiaria brizantha, cv Marandu, to $70^{\circ} \mathrm{C}$ between 5 and $30 \mathrm{~h}$ proved to be an efficient method to break dormancy (Martins \& Silva, 2006).

Pre-soaking seeds in boiling water for 5 or 15 min, regardless of the substrate, also caused a reduction in the germination percentage. Similar results were found for Satureja montana (Boscagli \& Sette, 2001). Furthermore, studies of Teles et al. (2000) with Leucaena leucocephala (Lam.) Wit, Barbosa et al. (2004) with Ochroma lagopus SW. Bombacaceae, and Gupta (2001) with Argyre nervosa and Urena lobata, pre-soaked in hot water at $80^{\circ} \mathrm{C}$ until cooling off, showed that this is a very effective method of breaking dormancy in these species. Again, the results for $O$. lagopus differ from those for "quina"; soaking the seeds of the former in water for 24 and $48 \mathrm{~h}$ had no effect on germination, whereas "quina" showed very satisfactory results, with a mean germination of over $96 \%$ when pre-soaked for $48 \mathrm{~h}$ (Teles et al., 2000).

However, cooling the seeds to $5^{\circ} \mathrm{C}$ during 7 days, regardless of the substrate, subjected to 200 ppm gibberellic acid and mechanical scarification, had no effect on the percentage of germinated seeds. On the other hand, results of seeds pre-soaked in gibberellic acid at 100 or 200 ppm, immersed in water for 24 or 48 $\mathrm{h}$ and kept on water-soaked substrate, and the same treatments except for 200 ppm gibberellic acid on the substrate with $\mathrm{KNO}_{3}$, were better than those of the control. Among the positive results for both substrates, seeds pre-soaked in water for 24 or $48 \mathrm{~h}$ and gibberellic acid in the water-soaked substrate had higher germination rates. Contrary to the results found here, in Caesalpinia ferrea Mart. ex Tul. the mechanical scarification with sandpaper No. 40 was efficient to break dormancy (Lima et al., 2006), as also observed in "chichá" (Sterculia foetida L.) seeds (Santos et al., 2004). Unlike the results for "quina", pre-soaking the endocarp of "umbuzeiro" (Spondias tuberosa His Câm.) in water during $0,48,96$ and $144 \mathrm{~h}$ did not positively influence germination (Costa et al., 2001).

When potassium nitrate was used in the germination substrate, "quina" seeds showed no response to this salt. On the other hand, seeds of "mate" (Ilex Paraguariensis) (Cuquel et al., 1994) and B. brizantha cv. Marandu (Garcia \& Cicero, 1992) responded positively to this treatment.

Potassium nitrate stimulates germination by helping suppress the tegument impermeability to gases, besides being a co-factor for the phytochrome action. Since germination success requires a combination of environmental factors, the interaction among temperature, light and nitrate has been amply studied. In contrast, gibberellin weakens the cell walls by hydrolases species, such as cellular mannanases, arabinosidases and expansins. They also stimulate the synthesis of á-amylase, which mobilizes endosperm reserves for the embryo development, besides boosting the transcription of á-amylase mRNA, demonstrating hormonal control on the gene expression (Guimarães, 1999, Resende et al., 2009).

These results show that the dormancy of "quina" seeds is most likely of morphological and physiological nature. It is physiological, as shown by the positive effect on germination when seeds were soaked in 200 ppm gibberellic acid, which increased the endogenous concentration of this germinationpromoter hormone. It is also morphological since presoaking in water during 24 to $48 \mathrm{~h}$ caused seed tegument softening, facilitating radicle protrusion.

\section{CONCLUSION}

Pre-soaking seeds in water during 24 or 48 $\mathrm{h}$, regardless of the substrate, or pre-soaking in 200 ppm gibberellic acid during $48 \mathrm{~h}$ on water-moistened substrate, led to the best results. Of the two possibilities, immersion in water is more appropriate, for being economically more viable.

\section{ACKNOWLEDGEMENT}

The authors are indebted to CNPq for the undergraduate research program scholarship to the first author; to Mr Arlindo Thomaz da Silva and his family for donating the plant material used here; and to Dr. Fernanda Ribeiro Queiroz de Oliveira for her critical reading and correction of the manuscript in Portuguese.

Rev. Bras. PI. Med., Botucatu, v.13, n.4, p.507-511, 2011. 


\section{REFERENCE}

ALMEIDA, S.P. et al. Cerrado: espécies de vegetais úteis. Planaltina: EMBRAPA/CPAC, 1998. 464p.

BARBOSA, A.P. et al. Tecnologia alternativa para a quebra de dormência das sementes de pau-de-balsa (Ochroma lagopus Sw., Bombacaceae). Acta Amazônica, v.34, n.1, p.107-10, 2004.

BOSCAGLI, A.; SETTE, B. Seed germination enhancement in Satureja montana L. spp. Montana. Seed Science \& Technology, v.29, n.2, p.347-55, 2001.

BUSCHBACHER, R. Expansão agrícola e perda da biodiversidade do Cerrado: origens históricas e o papel do comércio internacional. Brasília: WWF Brasil, 2000. 99p. CARDOSO, T.V. Tolerância à dessecação e germinação de quina (Strychnos pseudoquina A. St. Hil.). 2007. 27p. Monografia (Trabalho de Conclusão de Curso) - Centro Federal de Educação Tecnológica de Rio Verde, Rio Verde.

CARMONA, R.; FERGUSON, J.R.; MAIA, M.S. Germinação de sementes em Stylosanthes macrocephala M. B. Ferreira \& N.M. Sousa Costa Vog. in Linnaea. Revista Brasileira de Sementes, v.8, n.3, p.19-27, 1986.

COSTA, N.P. et al. Efeito do estádio de maturação do fruto e do tempo de pré-embebição de endocarpos na germinação de sementes de umbuzeiro (Spondias tuberosa Arr. Câm.). Revista Brasileira de Fruticultura, v.23, n.3, p.738-41, 2001.

CUQUEL, F.L.; CARVALHO, M.L.M.; CHAMMA, H.M.C.P. Avaliação de métodos de estratificação para a quebra de dormência de sementes de erva-mate. Scientia Agrícola, v.51, n.3, p.415-21, 1994.

DOUSSEAU, S. et al. Superação de dormência em sementes de Zeyheria montana Mart. Ciência \& Agrotecnologia, v.31, n.6, p.1744-8, 2007.

FERREIRA, S.A.N.; GENTIL, D.F.O. Extração, embebição e germinação de sementes de tucumã (Astrocaryum aculeatum). Acta Amazônica, v.36, n.2, p.141-5, 2006. GARCIA, J.; CÍCERO, S.M. Superação de dormência em sementes de Brachiaria brizantha CV. Marandu. Scientia Agricola, v.49, n.1, p.9-13, 1992.

GUIMARÃES, R.M. Fisiologia de sementes: produção e tecnologia de sementes. Lavras: UFLA/FAEPE, 1999. $129 p$.

GUPTA, V. Structural changes in seed coat morphology during dormancy breaking in some medicinal plants. Journal of Medical and Aromatic Plant Science, v.2223, n.4A-1A, p.672-3, 2001.

HERMANSEN, L.A.; DURYEA, M.L.; WHITE, T.L. Variability in seed coat dormancy in Dimorphandra mollis. Seed Science Technology, v.28, n.3, p.567-80, 2000.

LIMA, J.D. et al. Efeito da temperatura e do substrato na germinação de sementes de Caesalpinia ferrea Mart. ex Tul. (Leguminosae, Caesalpinoideae). Revista Árvore, v.30, n.4, p.513-8, 2006.

LOPES, J.C.; DIAS, P.C.; MACEDO, C.M.P. Tratamentos para acelerar a germinação e reduzir a deterioração das sementes de Ormosia nitida VOG. Revista Árvore, v.30, n.2, p.171-7, 2006.

MAGUIRRE, J.D. Speed of germination aid in selection and evaluation for seedling and vigour. Crop Science, v.2, n.2, p.176-7, 1962.

MARCOS FILHO, J. Fisiologia de sementes de plantas cultivadas. Piracicaba: FEALQ, 2005. 495p.

MARTINS, L.; SILVA, W.R. Ações fisiológicas do calor e do ácido sulfúrico em sementes de Brachiaria brizantha cultivar Marandu. Bragantia, v.65, n.3, p.495-500, 2006. MENEGHELLO, G.E. et al. Tratamentos para superar a dormência de sementes de Enterolobium contortisiliquum (Vel.) Morong. Agropecuária Clima Temperado, v.3, n.2, p.199-204, 2000.

NADEEM, M. et al. Propagation and conservatiion of Podophyllum hexandrum Royle: na important medicinal herb. Biological Conservation, v.92, n.1, p.121-9, 2000. NICOLETTI, M. et al. Flavonoids and alkaloids from Strychnos pseudoquina. Journal of Natural Products v.47, n.6, p.953-7, 1984.

RESENDE, M.L. et al. Influência da luz e giberelina na velocidade de germinação das sementes de cafeeiro (Coffea arabica L.). Coffee Science, v.4, n.2, p.149-54, 2009.

SANTOS, T.O.; MORAIS, T.G.O.; MATOS, V.P. Escarificação mecânica em sementes de chichá (Sterculia foetida L.). Revista Árvore, v.28, n.1, p.1-6, 2004.

SILVA, M.A. et al. Evaluation os Strychnos pseudoquina St. Hil. leaves extract on gastrointestinal activity in mice. Chemical \& Pharmaceutical Bulletin, v.53, n.8, p.881-5, 2005.

TELES, M.M. et al. Métodos para quebra da dormência em sementes de leucena (Leucaena leucephala (Lam.) de Wit). Revista Brasileira de Zootecnia, v.29, n.2, p.38791, 2000.

VIEIRA, A.R. et al. Action of gibberellic acid $\left(\mathrm{GA}_{3}\right)$ on dormancy and activity of á-amylase in rice seeds. Revista Brasileira de Sementes, v.24, n.2, p.43-8, 2002.

WUTKE, E.B. et al. Superação da dormência de sementes de mucuna-preta pela utilização de "calor seco". Scientia Agricola, v.52, n.3, p.482-90, 1995. 